\title{
組立式軽量高剛性構造パネルの曲げ剛性評価
}

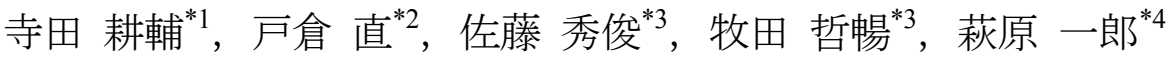

\section{Evaluation of the bending stiffness on assembled light weight and high strength panel}

\author{
Kousuke TERADA ${ }^{* 1}$, Sunao TOKURA ${ }^{* 2}$, Hidetoshi SATO*3, \\ Akinobu MAKITA*3 and Ichiro HAGIWARA ${ }^{* 4}$ \\ ${ }^{* 1,{ }^{* 3}}$ Adovanced Course in Mechanical and Electrical System Engineering, National Institute of Technology, Fukushima College \\ 30 Aza-Nagao, Tairakamiarakawa, Iwaki-shi, Fukushima 970-8034, Japan \\ ${ }^{* 2}$ Tokura simulation research corporation, 3-36-1-801 Abiko, Abiko-shi, Chiba 270-1166, Japan \\ ${ }^{*}$ Meiji Institute for Advanced Study of Mathematical Sciences, 4-21-1 Nakano, Nakano-ku, Tokyo 164-8525, Japan
}

Received 23 April 2015

\begin{abstract}
Honeycomb panel is widely applied into various structures such as lightweight and high stiffness panel. The glued honeycomb panel may catch fire. That's why some new high stiffness technologies have been developed. As a result of that, Truss Core Panel (TCP) has recently been developed. TCP has equivalent bending stiffness as honeycomb panel, and stronger in shear and more fire resistant than honeycomb panel. However, it is difficult in general to form TCPs compared to honeycomb panel. Therefore, multi-stage press forming process was investigated, but it cannot manufacture its structure with high aspect ratio for the limit of press forming process. The main aim of our research is to develop a new manufacturing process for Assembled Truss Core Panel (ATCP) by using bending method, suggesting the possibility to make much wider range of structures than before. In this paper, firstly we show the results of the trial product to confirm the ability of manufacturing ATCP. Then we evaluate the bending stiffness of the trial product of ATCP by measurements and FEM analysis. Finally, we conclude ATCP can be manufactured with high aspect ratio and the bending stiffness of ATCP can be estimated at the design-planning stage by FEM analysis. Some tasks on the development of ATCP will be presented by us in the near future.
\end{abstract}

Key words : High stiffness panel, Honeycomb panel, Truss core panel, Bending stiffness, Bending method, FEM

\section{1. 緒言}

昨今の世界各地を襲う集中豪雨による土砂災害は，地球温暖化で海面からの水蒸気増加によって積乱雲が多発 したことが主要因の一つとされている。世界的に地球温暖化問題の解決は急務となっており，産業活動から排出 された二酸化炭素の量を減らす必要性が指摘されている，その解決法の一つとして，軽量高剛性構造パネルを自 動車，航空機などの輸送機器に応用し，燃費向上による化石燃料と環境污染物質等の削減が挙げられる。また， 土石流や地震等の災害時でも耐えうるように，建築物を効果的に補強できる軽量高剛性構造パネルのニーズも大 である。

現在のところ，代表的な軽量高剛性構造パネルとしてもっともよく知られているハニカムコアパネル（HCP : Honeycomb Core Panel） は様々なコアサイズ，パネル寸法のものが比較的容易に製作でき，曲げ岡性に優れてい るため産業界で多く活用されている. 特に, 1949 年に米軍機に初めて搭載された後，様々な改良が加えられ，現

No.15-00039 [DOI: 10.1299/transjsme.15-00039], J-STAGE Advance Publication date : 1 July, 2015

*1 正員，(独)国立高等専門学校機構 福島工業高等専門学校 機械電気システム工学専攻 川字長尾 30)

*2 正員，(株) トクラシミュレーションリサーチ（†270-1166 千葉県我孫子市我孫子 3-36-1-801)

*3 学生員, (独)国立高等専門学校機構 福島工業高等専門学校 機械電気システム工学専攻

*4 正員, フェロー, 明治大学 先端数理科学インスティテュート（†164-8525 東京都中野区中野 4-21-1 明治大学中野キャンパス）

E-mail of corresponding author: k-terada@fukushima-nct.ac.jp 
在では一般的な航空機体構造に利用されている。しかし，HCP は，接着剂を使用しコア強度が接着剂の特性に依 存するため耐熱性に限界がある，耐せん断性が低い，製造コストが高い等の欠点もあることで，より広範な利用 が妨げられている.

そこで，正 3 角形からなる正 4 面体 (図 1 (a)）と正 8 面体（図 1 (b)）を用いた平行菱形 6 面体（図 1 (c)，(d)） を構成して空間充填（図 1 (e) ) すると, その稜線形状はオクテット・トラスと呼ばれる強固な構造として知られ ているが，この考え方を元にしてトラスコアパネル(TCP : Truss Core Panel)が提案されている(齐藤, 野島, 2007, 2008, 2012, 斉藤他, 2009). タイプとしてはダブルとシングル（図 2）とがある(萩原, 2013）。

TCP は，図 2 に示寸ように，周期的な四面体形状の凹部を三角形のグリッド上に成形したパネルから構成され ている.この構造パネルは HCP と同程度の曲げ剛性を持ち, かつせん断強度, 面内圧縮特性に優れ, さらに接着 剂を使用することなく金属材料のみで製造可能なため, 火災時の安全性が高いというメリット等を有すると報告 されている(萩原, 2011). TCP を機械構造部品に適用するための加工法としては, プレス成形, ハイドロフォー ミング，超塑性成形などがあるが，八イドロフォーミングや超塑性成形は成形コストが高く，単純なプレス成形 では三角錐形状をしたコア成形において頂点近傍に大ひずみが局所的に発生する問題がある. 戸倉らは，その解 決策として, 多工程プレス成形法を提案している.しかし, 多工程プレス成形法でも, 汎用的な鋼材の場合, 三 角錐の高さ $d$ と底面の辺の長さ $c$ の比をアスペクト比 $f$ (図 $3(\mathrm{~b})$ ) と寸ると, その限界は 0.29 と報告されてい る(戸倉, 萩原, 2008)。TCP の曲げ剛性は $f$ が大きいほど高い故に, $f$ に制限がある問題は大きい.

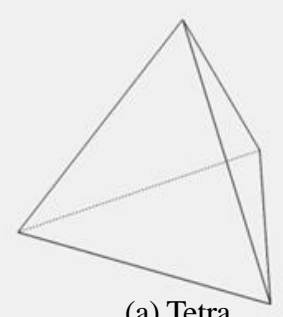

(a) Tetra

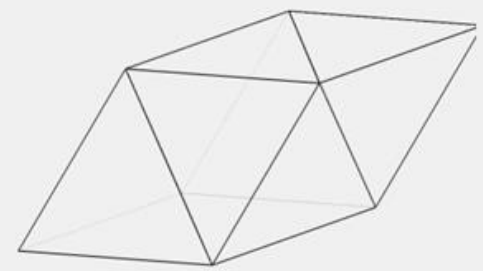

(d) Rhombohedron

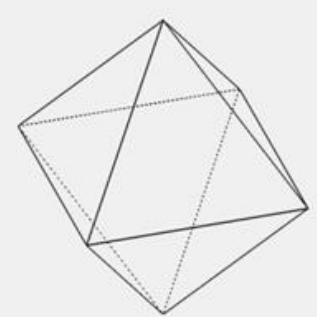

(b) Octahedron

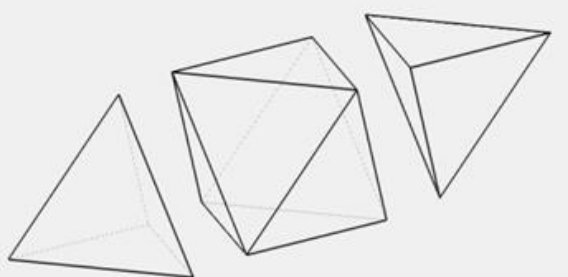

(c) Tetra and octahedron

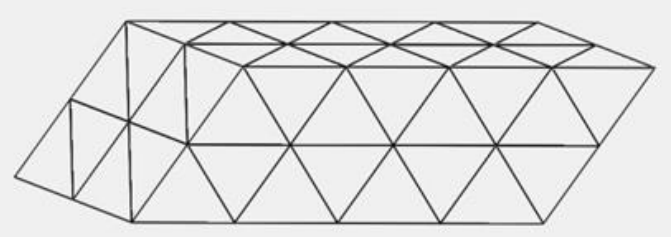

(e) Space filling

Fig.1 Octet truss structure. It consists of tetra and octahedron. ATCP, which is constructed as many tetra and octahedron cores, can be applied to octet truss structure.

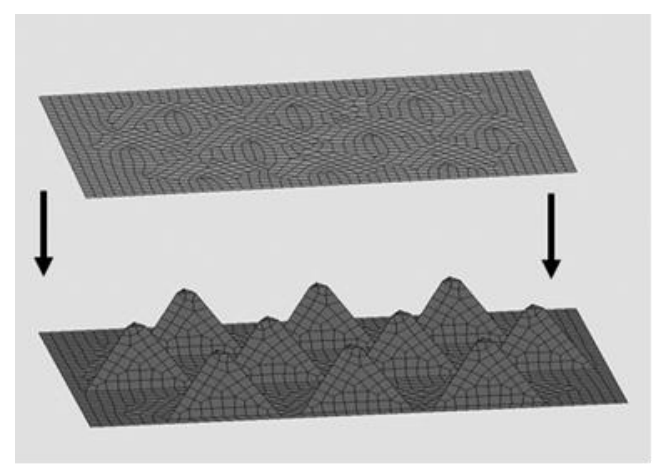

(a) Single TCP

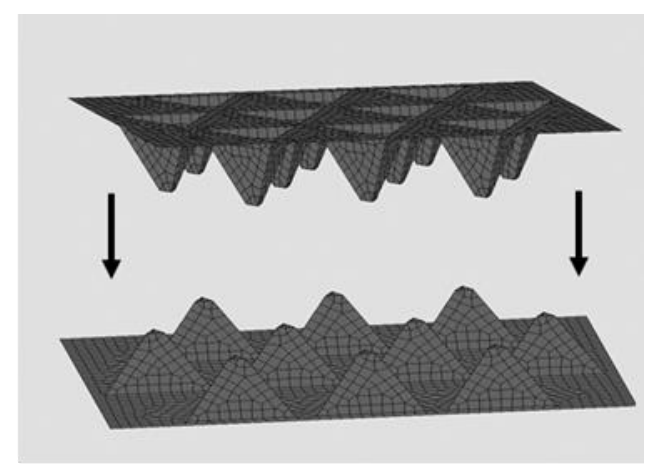

(b) Double TCP

Fig.2 Two types of Truss Core panel . A recess periodic tetrahedron on a grid of triangles is in one panel side or two panel sides. 


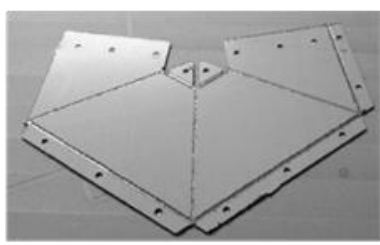

(a) 2D Deployment for a core

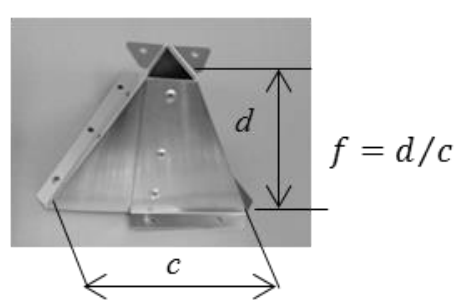

(b) Produced core by bending

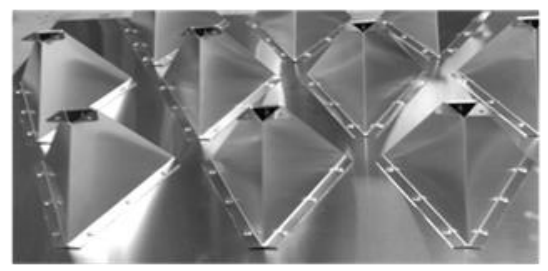

(c) Assembly process by using many cores

Fig.3 Proposed assembled Truss Core panel (ATCP) in this paper. The core mass production is performed by bent process using dedicated jigs. Finally, ATCP can be produced by assembling them.

また，プレス成形法では，スプリングバック対策等の成形補正工程が必要となる場合があり，これが製造コス トを押し上げる要因となっている，設計許容寸法精度内に成形できるまでトライアル試作による型開発期間を要 することがあるため, 各種の輸送機器や重機械等における多品種少量生産の場合には, 型設計と型製作費用を考 慮するとプレス成形法の適用は採算的に難しいこともある.

このような背景により，HCP に匹敵し低コストで加工可能な新しい TCP 構造と工法の研究開発が期待されて いる. ここでは, 新しい軽量高剛性構造パネルとして, 図 3 に示す曲げ加工でコアを必要数分造りそれらを組立 てることによって製造する組式立トラスコアパネル (ATCP) 工法と構造を提案する. 本稿では, その可能性を実証 するため ATCP を試作し, 試作品 ATCP の曲げ岡性測定実験と設計計画段階における曲げ岡性評価のために有限 要素解析 (FEM) による曲げ剛性評価手法の有効性検証等を行い, 得られた知見と今後の課題について報告する.

\section{2. 提案する組立式トラスコアパネルエ法と構造の特徵}

\section{$2 \cdot 1$ 曲げ加エと組立による利点}

これまでの HCP および TCP 工法の問題点等を解決するために，提案している ATCP 製造工法と構造の利点は 次のとおりである.

・この工法では工程数は多いが，コアの形状自由度が高く, プレス金型が不要であるため, 従来のプレス成形で は採算的に対応できない多品種少量生産にも適用できる.

・曲げ加工で多種多様の寸法形状のコアを大量生産し組立を行えば，正 3 角形からなる正 4 面体と正 8 面体を用 いた平行菱形 6 面体を構成して空間充填することにより, 曲面形状の ATCP も可能となる.

\section{$2 \cdot 2$ スプリングバックの抑制}

三角錐型コア曲げ加工においては，所定の曲げ角度に精度良く加工するためには，スプリングバックを抑制す る必要がある. 主なスプリングバック抑制方法としては, “決め押し”と“溝掘り”が知られている. 前者では, 曲げ加工において素材板厚を圧下寸ることによってスプリングバックを抑制する(小川，吉田，2012）。これに対 して, 後者では, 折り曲げ線上に素材板厚の約半分の深さの溝を設定し, 曲げ加工部の板厚を薄肉化することに よってスプリングバックを抑制する（小川，牧野内，1999）。三角錐型コアの曲げ加工における決め押しについて の報告(グエン・タイ・タット・ホアン他，2014)によると素材板厚圧下のための加圧設備およびそれに伴う治工 具類等の設備が必要となる. 所定の曲げ角度に対して $\pm 0.2^{\circ}$ 以内と寸る鉄鋼材料の場合の板厚圧下量は $0.03 \mathrm{~mm}$ 以上としている．また，板厚圧下に必要となる高強度な治具類の干渉を防ぐための治具形状および位置と移動に 関する制御についても詳細な検討を必要としている. これに対して, 後者に必要となる設備は, NC ルータ（図 4) やマシニングセンター, フライス加工等であり, 前者に比較すると設備は簡便である. また, 折線部の溝掘りに より薄肉化された部位は曲げ加工しやすく, 曲げ曲げ戻しにより所定の曲げ角度範囲以内にスプリングバックを 制御できる. しかし, 溝掘りの溝寸法（深さ, 幅）や溝形状（矩形, 半円, 楕円など）によってスプリングバッ クは変化するため, 適正な曲げ曲げ戻し要領も異なってくる. このような設計変数によるスプリングバックへの 影響についての筆者らの実験や解析を用いたアプローチは，別稿において報告したい，本稿では，溝掘りの場合 に, よく用いられている加工法を採用した. 即ち, 10000〜 18000rpm の高速回転で Vーカッタードリル刃(径 $3 \mathrm{~mm}$, 
先端角約 $90^{\circ}$ ) を用いて板厚の半分程度溝掘り加工し, 曲げ加工においては所定の曲げ角度範囲以内になるまで 曲げ曲げ戻しで角度調整している.

\section{$2 \cdot 3$ 接合法}

製造したコアの合わせ面の接合法としては, 溶接, ボルトナット, リベットなどが挙げられる. 溶接としては, レーザーやアークがあるが，接合後の熱変形や設備費が非常に高い等の問題がある．ボルトナットは，設備費は ほとんどかからないが，作業時間がかかることと裏面にナットをセットする作業空間がない場合も考えられるな どの欠点がある，これに対して，リベット，特にブラインドリベット(図 5) は, 設備費も安価であり, かつ裏面 からの作業を要しない利点がある，従って，ここでは，接合法としてブラインドリベットを採用する.

\section{3. 組立式トラスコアパネル試作品の仕様}

今回の試作では，ATCP 工法と構造の提案の有効性を示すことを目的とし，新しい初めての試みであることを 考慮し, 加工作業し易いサイズでかつ曲げ岡性測定装置(図 10)で実験できる最大サイズとし, 試作費用の制限等 も考慮してコア列は対称性がとれる最小の 3 ラインとして, 主な仕様を下記のように設定している. なお, 本試 作は，金属材料の折り曲げ加工で世界的に定評のある英国 Robofold 社の協力を得て行っている (寺田，2014).

(1) 素材：軽量で曲げ加工を行いや寸いアルミ合金 5000 系材料で板厚 $t 1.5 \mathrm{~mm}$ を用いている. 素材の材料定数

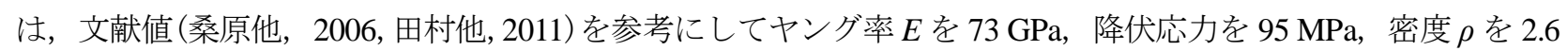
$\mathrm{g} / \mathrm{cm}^{3}$, ポアソン比を 0.33 , 接線係数を $700 \mathrm{MPa}$ としている.

（2）主要寸法(表 1) : 上記の寸法設定範囲から, 基本寸法である正 4 面体コアの平面状態の 1 辺の長さ $a$ を $200 \mathrm{~mm}$ とし，1 辺の両端の曲げ部分 $3 \mathrm{~mm}$ を差し引くと 3 角錐コア底辺長さ $c$ は $194 \mathrm{~mm}$ となる. コア総数 10 個 (3-4-3 列）のシングルタイプとしている. 試作品の形状寸法を図 6 に示す. 今回の試作品では, 締結確保できる必要最 低限のリベット点数とし，締結作業性を考慮して，寸法 $b, e \sim w$ 等を表 1 のように設定している.

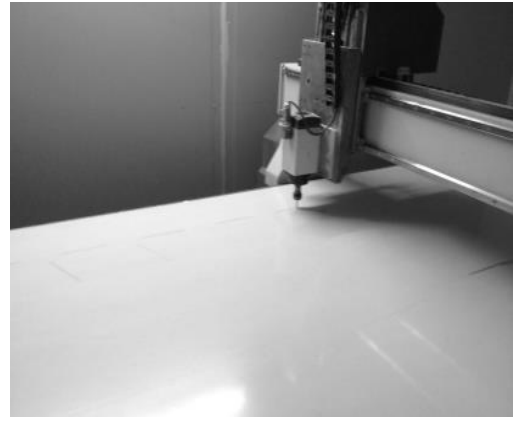

(a)

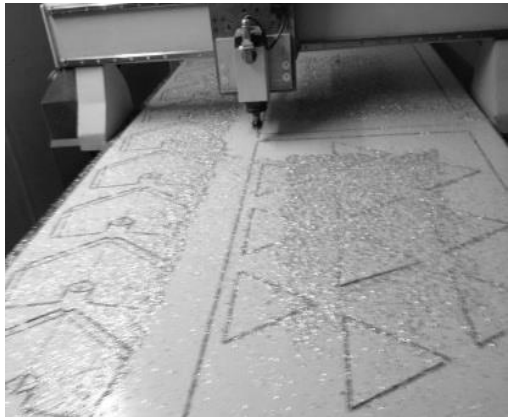

(b)

Fig.4 3-Axis CNC milling machine . (a) Start of making groove and cut lines . (b) Working process . This machine can be used to make groove and cut lines in metal sheets automatically.

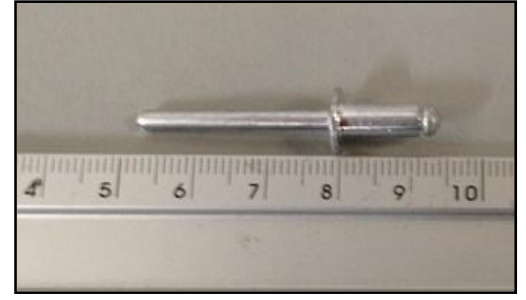

(a)

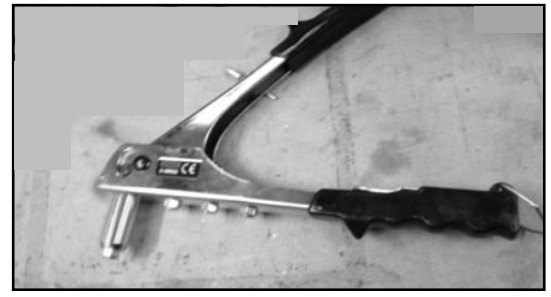

(b)

Fig.5 (a) An example of blind rivet. (b) Rivet instrument.

The cost of blind rivets is cheap. Setting works can be done freely by using rivet instruments. 


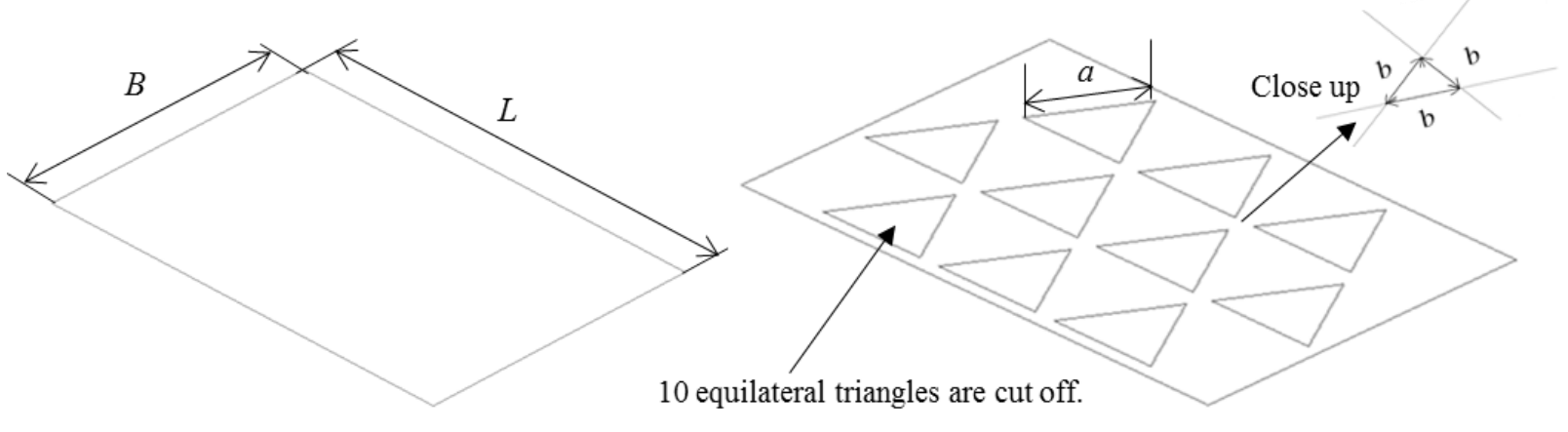

(a) Upper panel, B: Width, L: Length

(b) Lower panel
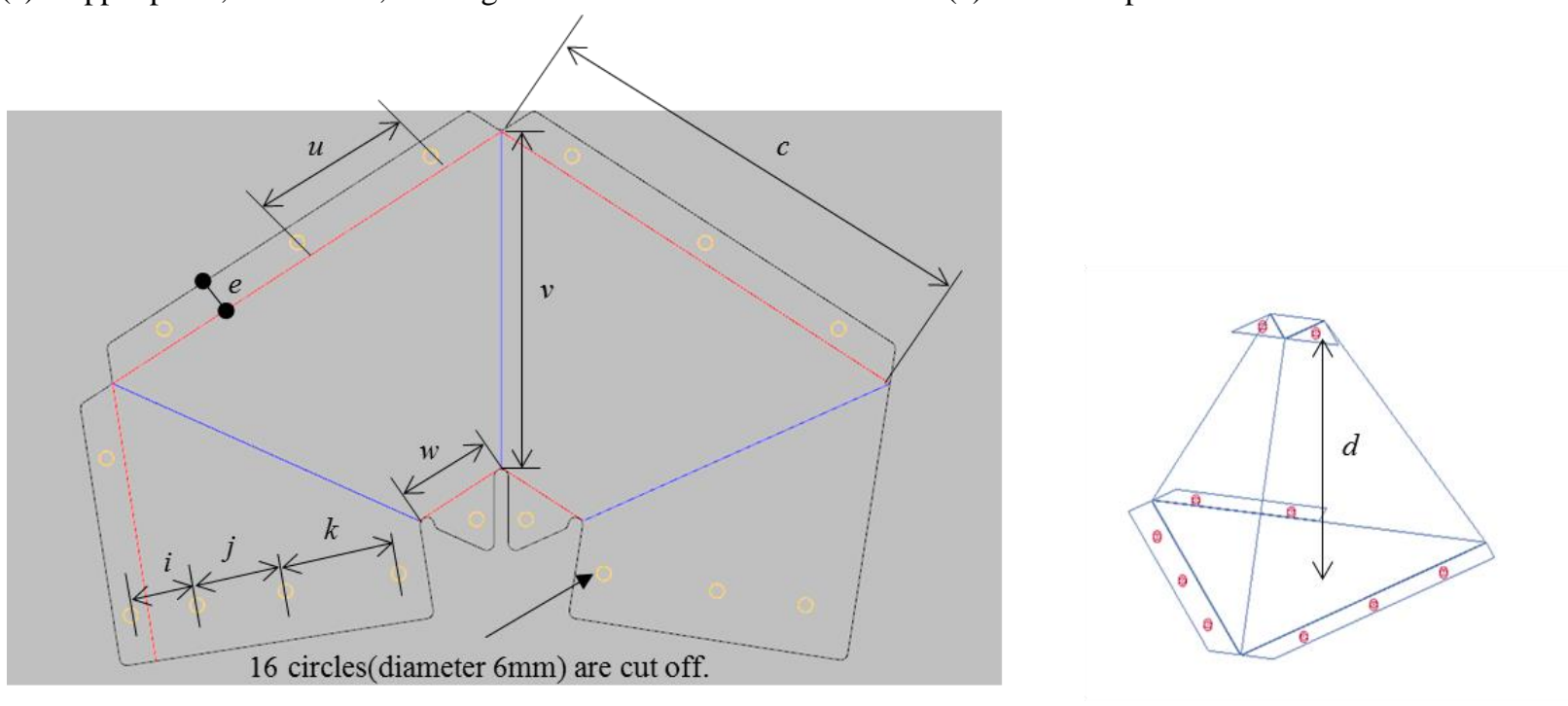

(c) 2D Deployment for a core

(d) Bent core

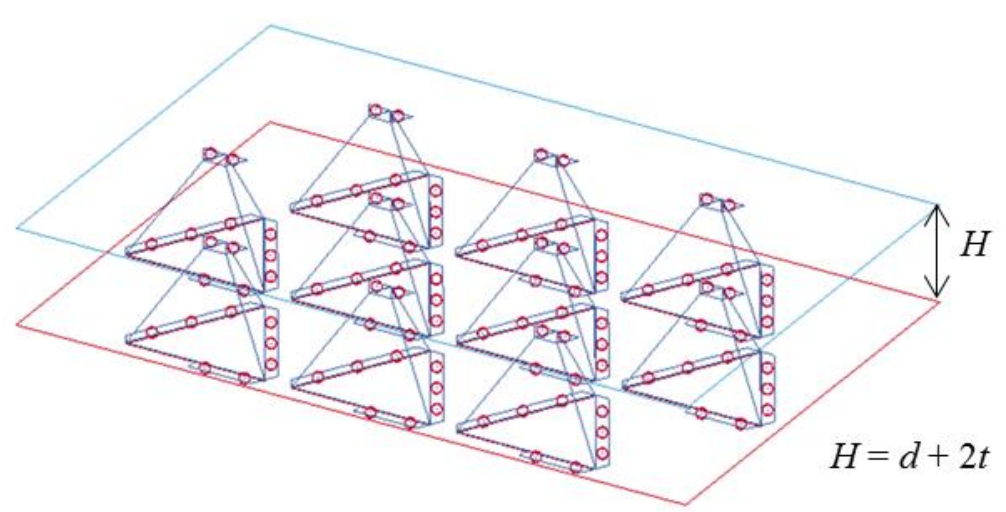

e) The prototype ATCP

Fig.6 Design plan of prototype ATCP. It is assembled with 2 plates and 10 cores.

Table 1 Major dimensions of prototype ATCP

\begin{tabular}{l|ccccccccccccccc}
\hline \hline Symbol & $a$ & $b$ & $c$ & $d$ & $e$ & $i$ & $j$ & $k$ & $t$ & $u$ & $v$ & $w$ & $B$ & $L$ & $H$ \\
\hline Dimension (mm) & 200 & 45 & 194 & 112 & 18 & 30 & 40 & 50 & 1.5 & 65 & 140 & 55 & 655 & 990 & 115 \\
\hline
\end{tabular}


（3） $\mathrm{NC}$ ルータでの加工 : 折り曲げ線上を $\mathrm{NC}$ ルータで溝(約 $0.7 \mathrm{~mm} \times 1 \mathrm{~mm}$ ) 掘り加工 (図 4) している. また，今 回の組立式トラスコアパネル試作品では，1枚の平板材からプレス加工で製造したトラスコアパネルと同等の外 形状にするため, 図6(b)に示すようにコアを取付ける箇所は, NC ルータで正三角形状の切り落とし加工を行 っている.

（4）コア曲げ加工：一般的にはスクリュープレスなどが用いられるが，今回の試作では，折線部は薄肉化されて いるため, 図 7 に示すようなハンディな治具で容易に曲げ加工が行える. また, 所定の曲げ角度範囲 $\left(60^{\circ} \pm 0.2^{\circ}\right)$ 以内に適合させるため, 曲げ曲げ戻し作業で角度調整している.このような溝堀り後の曲げ曲げ戻しによるスプ リングバック抑制メカニズムについての筆者らのアプローチは, 先述のように別稿で報告したい，このコア試作 品の $f$ は, $0.582 （=d / c=(115-1.5 \times 2) / 194)$, プレス加工での従来の限界值 $f$ の約 2 倍に向上している.

（5）接合〜組立：曲げ加工後のコアは，図８に示すように各合わせ面をブラインドリベットで接合している．今 回の組立作業時間は 1 時間程度である. 先の Nguyen らの報告では，接合法としては，レーザー溶接が提案され ていたが，設備導入費用は非常に高額であるため，今回の試作では設備費用を要しない工法を採用した．また， 全ブラインドリベットによる質量増加は約 $100 \mathrm{~g}$ 程度であり全体質量（1\%ほど）への影響は小さい.

（6）質量：試作完了後の質量測定を行った結果，試作品 ATCP(図 9)の質量 $W$ は $6544.9 \mathrm{~g}$ である.

以上のように，限定的な仕様ではあるが，今回の試作によりコアを曲げ加工で生産し組立てトラスコアパネル を製造することは技術的に可能であることが示された. 従来の TCPのようにプレス加工金型を必要とせず, HCP のように接着剤や複雑な組立工程なども不要である.ブラインドリベットを使用しているため外観は美しくない が，多品種少量生産の機械および建築構造物の内部構造補強材料として適用されることが期待できる.

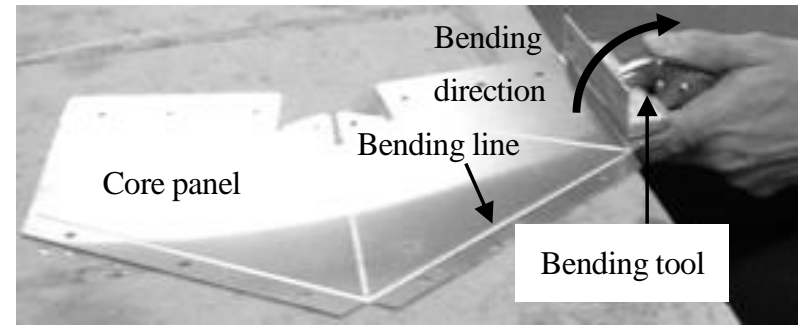

(a) A handy bending jig for core panel

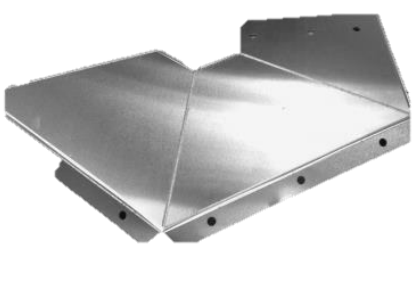

(b) Flanges are bent

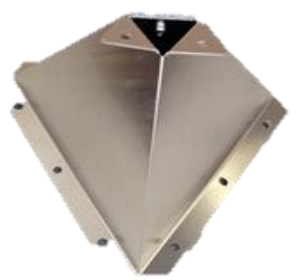

(c) Finished core by bending

Fig.7 Bending flow process. Core panels with groove lines can be bent easily by using a handy bending tool.

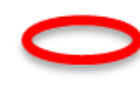

: Holes for attached faces,

: Holes for upper panels,

: Holes for lower panels

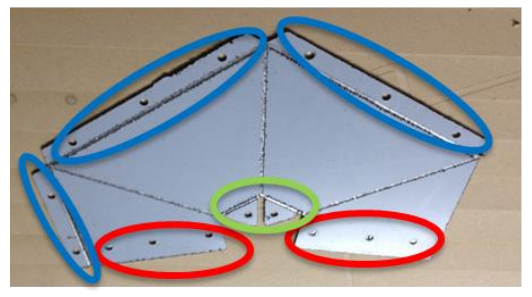

(a) 2D deployment

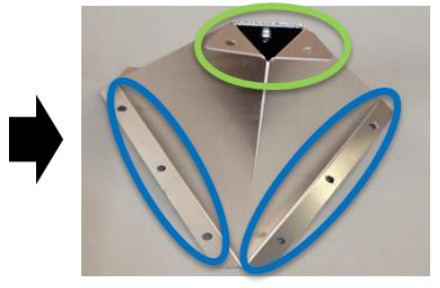

(b) After bending

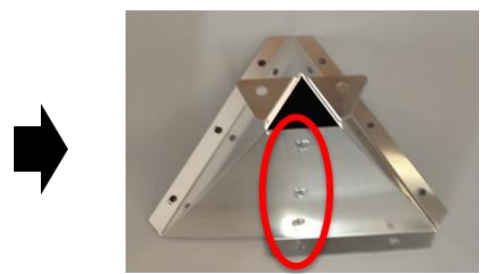

(c) Finished core attached by rivets

Fig.8 Core assembly flow process. Cores are produced by bending from 2D deployment and be assembled for ATCP as Fig.3. 


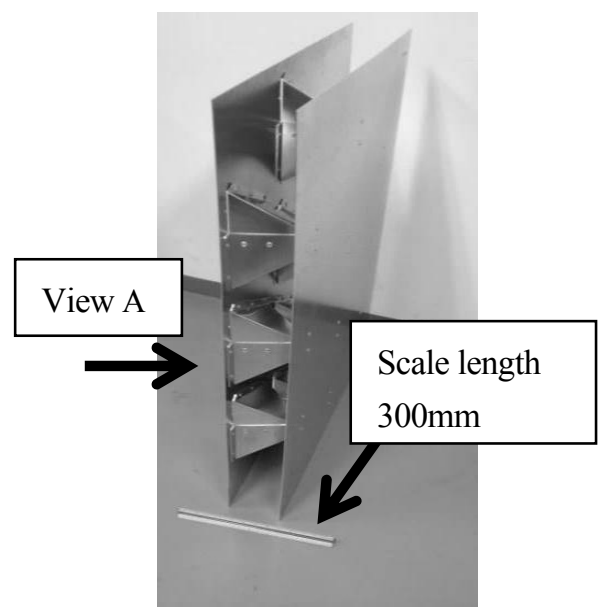

(a) Side view

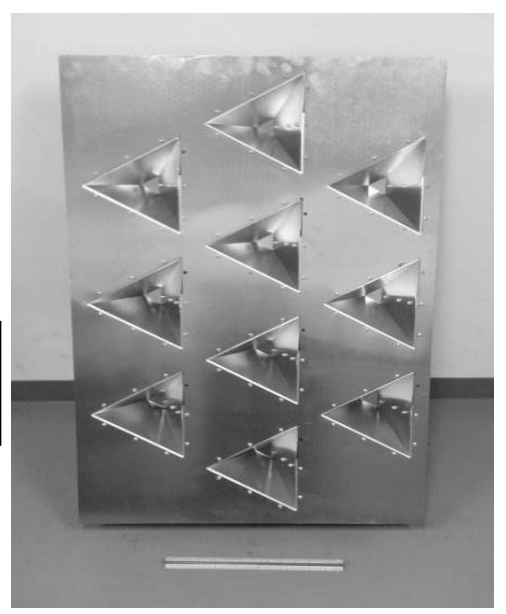

(b) View A

Fig.9 Photos of the prototype ATCP. It could be gotten successfully. The weight is $6544.9 \mathrm{~g}$.

\section{4. 試作品 ATCP の曲げ剛性評価と考察}

\section{$4 \cdot 13$ 点曲げ試験方法}

試作品 ATCP の曲げ剛性評価を，図 10 (a) に示す 3 点曲げ岡性試験により行う。この試験では，上面中央部に 一本の荷重治具, 下面両サイドに二本の円柱状治具を設置し試作品 ATCP セット後, Bed を上昇させながら, 100N ごとに荷重 $P$ と撓み $\delta$ （荷重治具の降下量）を測定して曲げ剛性 $D$ を評価する. 三本の円柱状治具として $\phi 22$ 丸鋼を, 試験機として株式会社 東京試験機製の油圧式万能試験機（機種 YU-2000S4, 図 10(b)）を用いている. この試験機の主な仕様を表 2 に示寸，なお，本試験における Bed 上昇速度は $0.5 \mathrm{~mm} / \mathrm{min}$ である.

\section{$4 \cdot 2$ 測定結果と曲げ剛性評価}

3 点曲げ試験によって得られた $P$ と $\delta$ の関係から, 次式(1)を用いて $D$ を評価する.

$$
D \cong \frac{(P / \delta) l^{3}}{48}
$$

ここで, $l$ は二本の治具支持間隔であり, 測定試験時は $l=776 \mathrm{~mm}$ としている.

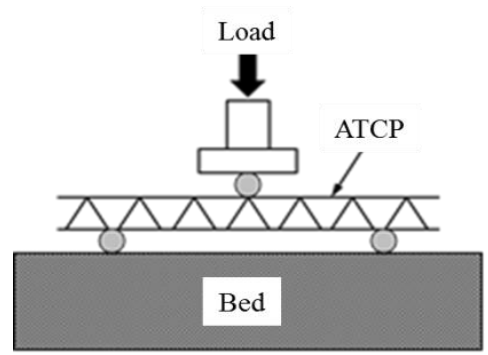

(a) 3 points bending mechanism

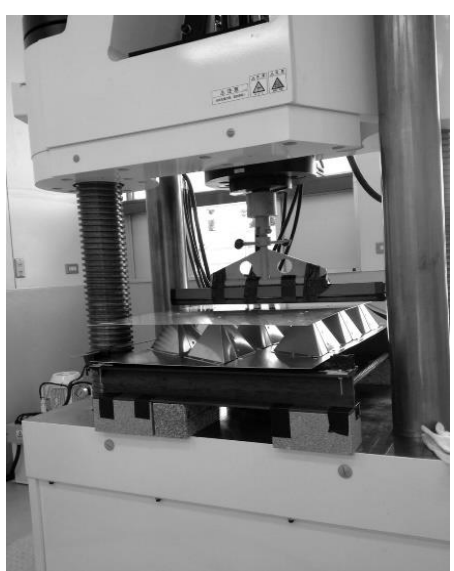

(b) Hydraulic system universal testing machine

Fig.10 The bending stiffness of this prototype ATCP was evaluated by 3 points bending mechanism, using a hydraulic system universal testing machine. 
曲げ剛性試験結果による $P$ と $\delta$ の関係を, 図 11 に示す. $P$ が $1000 \mathrm{~N}$ までは, $P$ と $\delta$ は概ね線形関係にあり, 試作品 ATCP は弹性変形している. $P$ が $1000 \mathrm{~N}$ を超えて, これまでの $P$ と $\delta$ の比例関係から離脱し非線形現象 を示し始めた時点で試験を終了した。試験結果から， $P / \delta=249.1(\mathrm{~N} / \mathrm{mm})$ となり，式(1)から

$D=2.43 \times 10^{3}\left(\mathrm{~N} \cdot \mathrm{m}^{2}\right)$ と算出される.

Table 2 Specifications of hydraulic system universal testing machine YU-2000S4

\begin{tabular}{l|c}
\hline \hline Press load & Max. $2000 \mathrm{kN}$ \\
\hline Interval of columns & $850 \mathrm{~mm}$ \\
\hline Tension distance & Max. $700 \mathrm{~mm}$ \\
\hline Compression distance & Max. $550 \mathrm{~mm}$ \\
\hline $\begin{array}{l}\text { Machine size } \\
\mathrm{W} \times \mathrm{D} \times \mathrm{H}\end{array}$ & $1400 \times 850 \times 3300 \mathrm{~mm}$
\end{tabular}

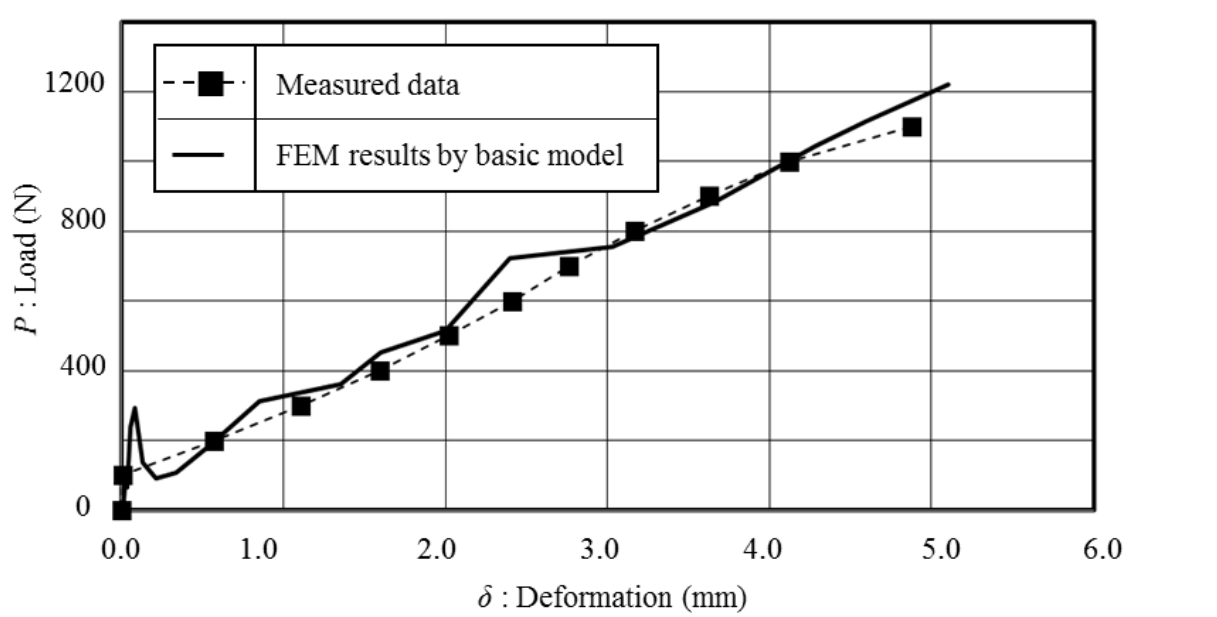

Fig.11 Comparison between measured data and FEM results for relationship $P$ and $\delta$. FEM results by basic model are in good agreement to measured data.

次に試作品 ATCP に対して同素材，同投影面積 $(L \times B)$ ，同重量の中実矩形断面からなる構造体を想定し，この 構造体の曲げ剛性 $D^{*}$ *評価する.即ち, 単純な板材の構造体になったとし, 幅 $B$ は $655 \mathrm{~mm}$, 長さ $L$ は $990 \mathrm{~mm}$, 試作品質量 $W$, 素材比重 $\rho 2.6$ をもとに，この構造体の断面厚さ $T(\mathrm{~mm})$ を式(2)から計算する.

$$
\begin{aligned}
T & =1000 \times W /(\rho \times L \times B) \\
& =6544.9 /(2.6 \times 990 \times 655 / 1000)=3.88(\mathrm{~mm})
\end{aligned}
$$

想定した構造体断面寸法は幅 $B \times$ 厚さ $T$ であるから, 曲げ岡性 $D^{*}$ は, 材料力学の公式から式(3)で表される.

$$
D^{*}=E \times B \times T^{3} / 12
$$

ここで，E は素材のヤング率 $73 \mathrm{GPa}$ である.

式(3)を計算すると, $D^{*}=2.33 \times 10^{2}\left(\mathrm{~N} \cdot \mathrm{m}^{2}\right)$ となる.

今回の試作品 ATCP はシングルタイプであるため, コアの空間充填率は約 50 \%程度であるが, その曲け岡性 $D$ は, 同素材, 同投影面積, 同重量の中実矩形断面からなる構造体の曲げ剛性 $D^{*}$ の約 10.4 倍 (=24.3/2.33)に高剛 性化されている. 
また，逆に，試作品 ATCP の曲げ剛性 $D$ と同等になる同投影面積 $(L \times B)$ のアルミ合金板材の厚さを式(3)から 計算すると $8.48 \mathrm{~mm}\left(=(12 \times D /(E \times B))^{1 / 3}\right)$ となる. したがって, 板厚に換算して, 約 $45.8 \%(=3.88 / 8.48)$ に軽量化 されている.

\section{4·3 FEM 解析による考察}

次に, 組立品として構成された ATCP の曲げ剛性評価を FEM 解析により行い, 実験結果をもとに解析精度を 検証し有効性を示すことができれば，設計計画段階において FEM 解析により組立条件の曲げ岡性への影響を検 討し用途に応じた ATCP 設計仕様を提案できる.ここでは, FEM 解析手法の概要, 曲げ岡性測定実験による解析 精度検証結果と FEM 解析を用いて ATCP の曲げ剛性の特徴についてのケーススタディ等について述べる.

(1) FEM 解析手法の概要 : 今回の試作品 ATCP の曲げ剛性試験を対象とした FEM 解析のための基本モデルを図 12 に示寸. FEM 解析ソルバーとしては, 市販ソフトである LS-DYNA ( LS-DYNA Version 971 User's Manual, 2012) を用いている. 本解析は静的な変形現象を対象としていることから, 陰解法で行っている. FEM モデル化では, ア ルミ合金板材をシェル要素(完全積分シェル要素タイプ)で表し，材料モデルとしては，3 点曲げ剛性試験では構 造パネルの弾性変形域の範囲に限定しているため, 塑性域の材料モデル定義が簡便である多直線近似等方弾塑性 体モデルを用いている. 先述の材料定数を入力し，その他の材料定数はデフォルト值でミーゼス降伏条件を使用 している.ブラインドリベットによる接合はスポット溶接要素でモデル化し, 溝掘り部に該当する箇所のシェル 要素の板厚は薄肉化している. その他, 両サイドと中央部の三本の丸棒治具は剛体モデルである. また, ”治具 と板材”および”板材と板材”の接触問題はペナルティ法で解析し, 摩擦係数および動摩擦係数等はすべて 0.1 としている. 解析条件としては, 両サイドの丸棒治具モデルは完全位置固定とし, 中央の荷重治具モデルを鉛直 下方に降下させている．この降下量を $\delta(\mathrm{mm})$, 荷重治具に必要な鉛直下方荷重を $P(\mathrm{~N})$ とする.

(2) 検証結果 : $P$ と $\delta$ を出力させた FEM 解析結果(図 11)により, 次のような検証結果を示す.

- 実験結果との比較 : $\delta=4.0 \mathrm{~mm}$ となる荷重 $P$ の FEM 解析結果は, 実験結果に近い約 $1000 \mathrm{~N}$ であり評価精度と して良い， 基本モデルの FEM 解析結果は，実験結果と同様に，200～1000 N までの範囲では $P$ と $\delta$ はほぼ線形 の関係を示している. また，実験結果と解析結果ともに，荷重 $P$ が $0 \sim 100 \mathrm{~N}$ ほどの初期段階では，微妙な非線 形現象が認められる。このように，FEM 解析結果は実験結果によく一致していることから，ATCP 設計計画段階 において, 曲げ岡性值を評価し用途に応じた ATCP 設計仕様（core 形状寸法, core 数, 空間充填率, 接合点数, 併せ面の接触面積, 接合方法など）を検討するために，この FEM 解析手法を適用できることが裏付けられる.

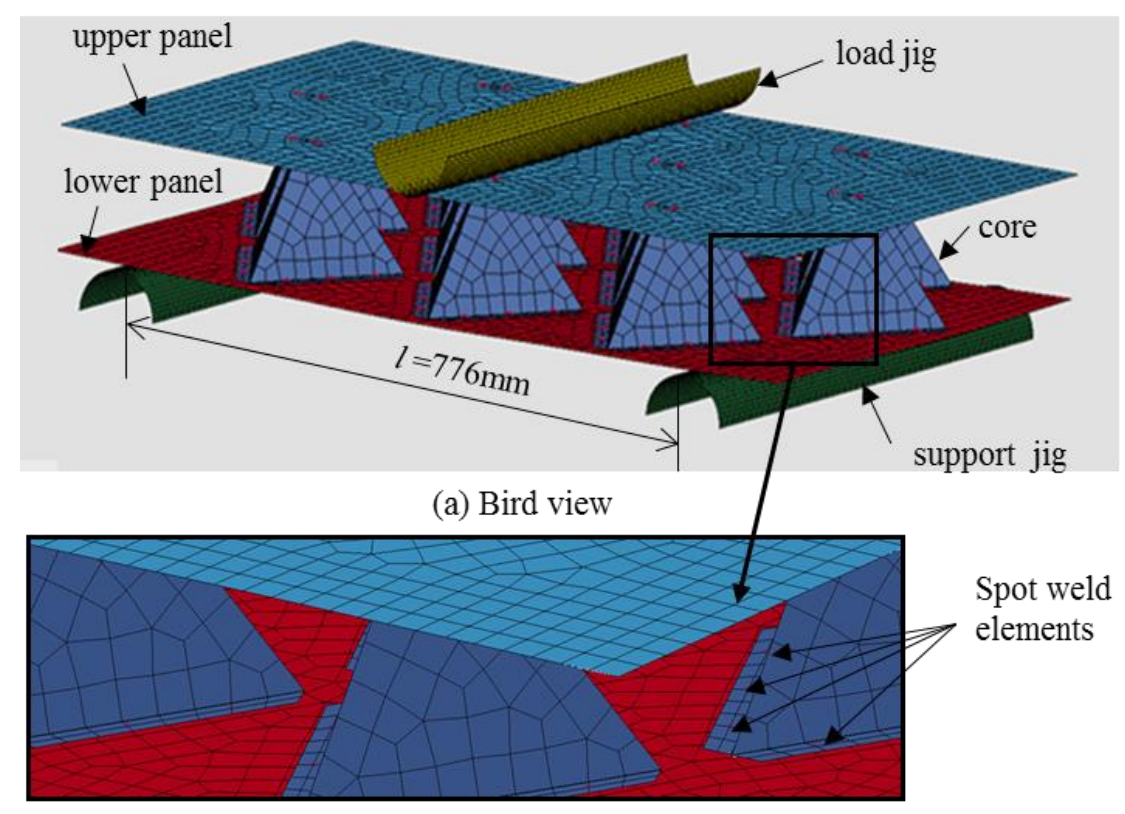

(b) Enlarged view

Fig.12 Basic model. This FEM model represents the prototype ATCP, which consists of 10 cores, upper panel and lower panel. 


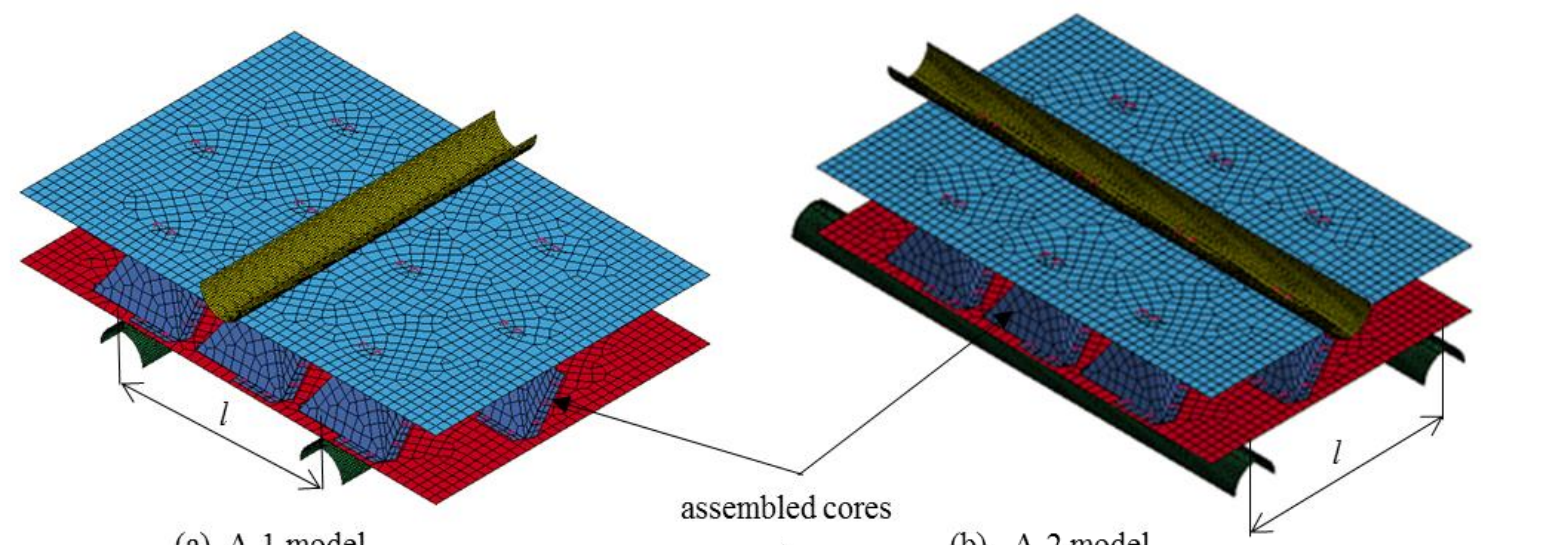

(a) A-1 model

(b) A-2 model

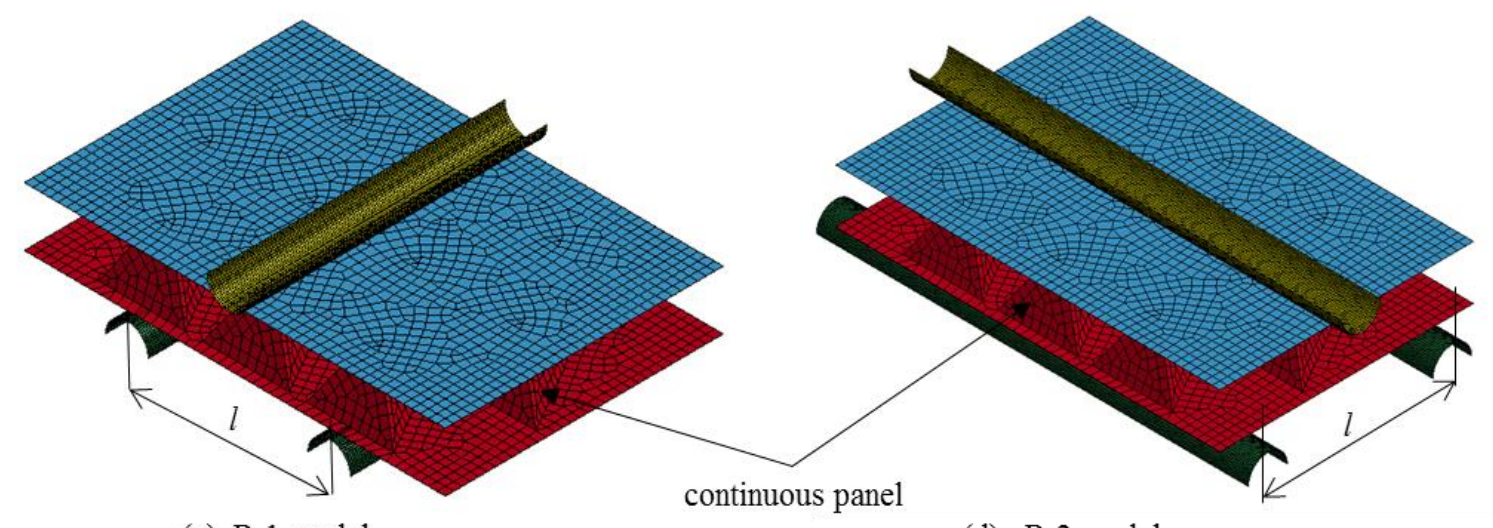

(c) B-1 model

(d) B-2 model

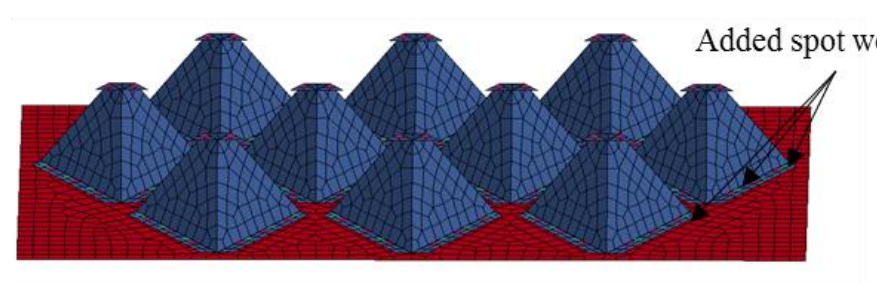

(e) $\mathrm{C}$ model

Fig. 13 Case study by FEM models at $l=476 \mathrm{~mm}$. (a) A model represents ATCP as the same as basic model. Total number of spot weld elements between cores and lower panel in A model is 80. A model is set on jigs along the width direction at A-1 model. (b) A model is set on jigs along the long direction at A-2 model. (c) B model represents virtual continuous structure. B model is set on jigs along the width direction at B-1 model. (d) B model is set on jigs along the long direction at B-2 model. (e) C model represents ATCP, which has 160 spot weld elements between cores and lower panel. Jigs layout of C-1 \& C-2 are the same as that of A-1 \& A-2 each.

(3) ケーススタディ: FEM 解析の有効性が示されたことにより, FEM 解析を用いて ATCP の曲げ岡性の特徴 について検討するために，次のようなケーススタディ(図 13)を行う.

a）組立条件 : core と upper panel, lower panel 等を組立て構成された今回の試作品を表す A モデル, 構成する板材 が完全な連続体からなる仮想的な TCP を表す B モデル，そして A モデルの core と lower panel とのリベット接合 点数を倍増させた $\mathrm{C}$ モデル等を設定する. A モデルの構造パネルは基本モデルと同様である. B モデルは，現実 的には製造することが極めて困難であるが，このような理想的な連続体構造パネルの FEM 解析結果と，組立条 件（合わせ面の接触面積, リベット接合点数など）を考慮した A モデルの FEM 解析結果とを比較することによ って, 組立条件の曲げ岡性への影響を検討することができる. 即ち， B モデルよりも $\mathrm{A}$ モデルの曲げ岡性の方が 低下するが，接合点数を増加させれば曲げ岡性は高くなるし，あるいは接合方法としてレーザー溶接を採用した ATCP の曲げ岡性ならば，B モデルの曲げ岡性とほぼ同等と想定される．このように A と B モデルの FEM 解析 からの曲げ岡性評価によって，用途に応じた適正な ATCP 設計仕様を検討することができると考えられる. 
b）治具設置位置：ATCP の曲げ岡性の異方性の特徵について検討するために，二本の support jig を構造パネルの 幅方向に平行に設置した場合と，長さ方向に平行に設置した場合を設定して FEM 解析を行う．A モデルを前者 のように設置したモデルを A-1 モデル，後者のように設置したモデルを A-2 モデルとする， B $\mathrm{C}$ モデルの場合も 同様の呼称である. なお，ケーススタディにおける二本の support jig 間の距離 $l$ は，前者と後者の場合でも同等 にするため，実験条件の場合より $300 \mathrm{~mm}$ 短い $476 \mathrm{~mm}$ に統一している.

以上のように，ここでのケーススタディは全 6 ケース $(=3 \times 2)$ である. ケーススタディによって，次の知見が 得られている.

a) 曲げ岡性評価 : FEM 解析結果から得られた $P$ と $\delta$ の関係グラフ例を図 14 に示し, 実験測定範囲の $\delta=5 \mathrm{~mm}$ までの全ケースの曲げ剛性平均值 $D$ と単位長さあたりの曲げ剛性平均值 $D^{\prime}$ (A モデルの場合 $D^{\prime}=D / B$

$(B=0.655 \mathrm{~m}), \mathrm{B}$ モデルの場合 $\left.D^{\prime}=D / L(L=0.950 \mathrm{~m})\right)$ の計算結果を表 3 に示寸. FEM解析による曲け剛性評価結果 は, 次のとおりである.

・A モデルの $D$ および $D^{\prime}$ に比べて, B モデルの方は約 5 倍高い.

・B モデルの $P$ と $\delta$ の関係は, $\delta$ が $2 \mathrm{~mm}$ までの領域でほぼ線形であるが，それを超える付近から傾きが若干小さ くなる非線形性がある.これに対して, A と C モデルの方は $\delta$ が $5 \mathrm{~mm}$ までの領域でほぼ線形関係を示している.

・C モデルの $D$ は，リベット接合点数を増加することによって，A モデルよりも約 $20 \%$ 高くなっている.

・ 3 モデルともに $D^{\prime}$ は, 二本の support jig が幅方向に平行に配置された場合の方が長さ方向に平行に配置された 場合よりも大きい. 即ち, 治具設置の方向を変更することによって, 3 モデルの曲げ剛性には異方性があること が示された.この異方性の度合いは, 3 つのモデルのなかでは B モデルがもっとも小さく $124 \%(=100 \times 7.38 / 5.97)$ の 変動を示し, A モデルが $135 \%(=100 \times 1.56 / 1.15), \mathrm{C}$ モデルが $148 \%(=100 \times 1.96 / 1.32)$ ともつとも異方性の度合 いが大きい.

次に, 3 モデルの曲げ岡性評価結果についての特徵がどのようなメカニズムから生じているかを, FEM 解析に より得られた構造体パネル内の応力分布/変位量分布から考察する.

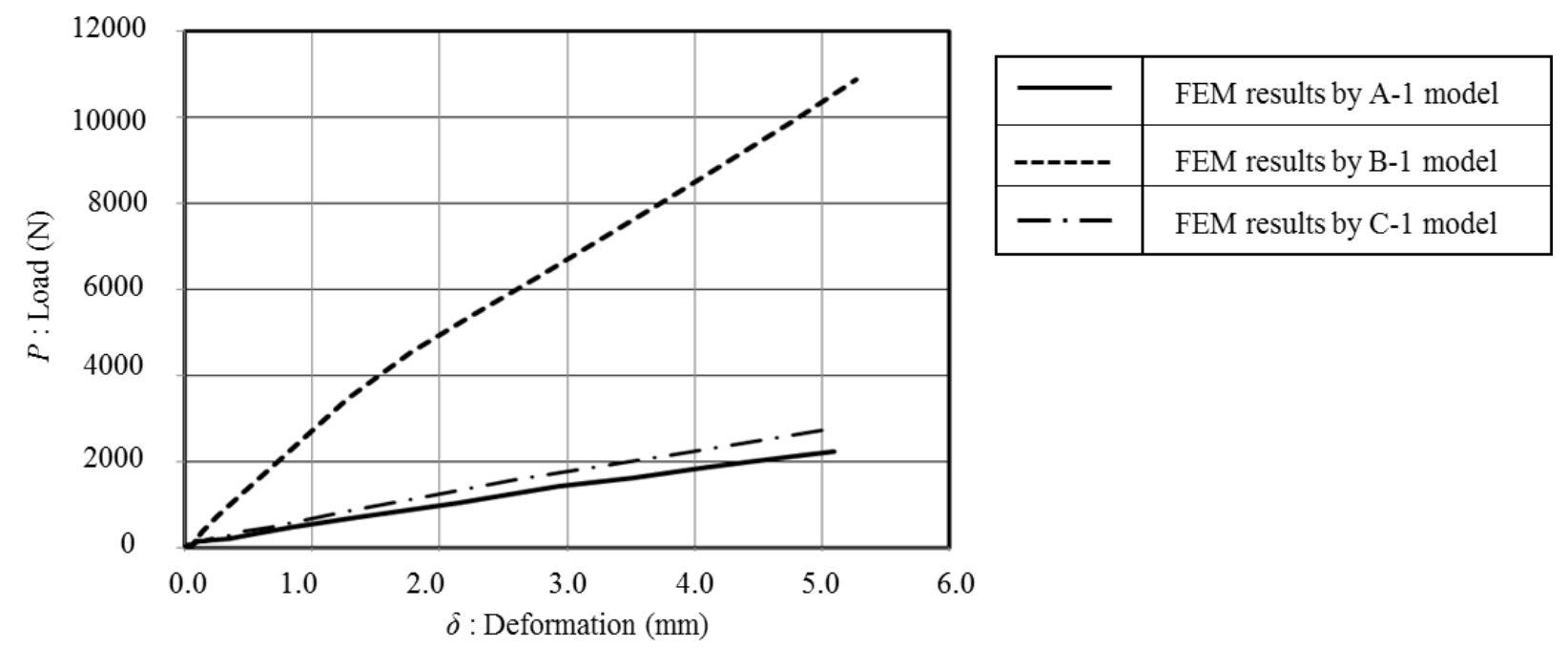

Fig.14 Comparison between 3 models by FEM results for relationship $P$ and $\delta$.

Table 3 Bending stiffness $D$ \& $D^{\prime}$ by FEM analysis

\begin{tabular}{c|cccccc}
\hline \hline Case & A-1 & A-2 & B-1 & B-2 & C-1 & C-2 \\
\hline$D\left(\mathrm{~N} \cdot \mathrm{m}^{2}\right)$ & $1.02 \times 10^{3}$ & $1.14 \times 10^{3}$ & $4.83 \times 10^{3}$ & $5.91 \times 10$ & $1.28 \times 10^{3}$ & $1.31 \times 10^{3}$ \\
\hline$D^{\prime}(\mathrm{N} \cdot \mathrm{m})$ & $1.56 \times 10^{3}$ & $1.15 \times 10^{3}$ & $7.38 \times 10^{3}$ & $5.97 \times 10^{3}$ & $1.96 \times 10^{3}$ & $1.32 \times 10^{3}$ \\
\hline
\end{tabular}




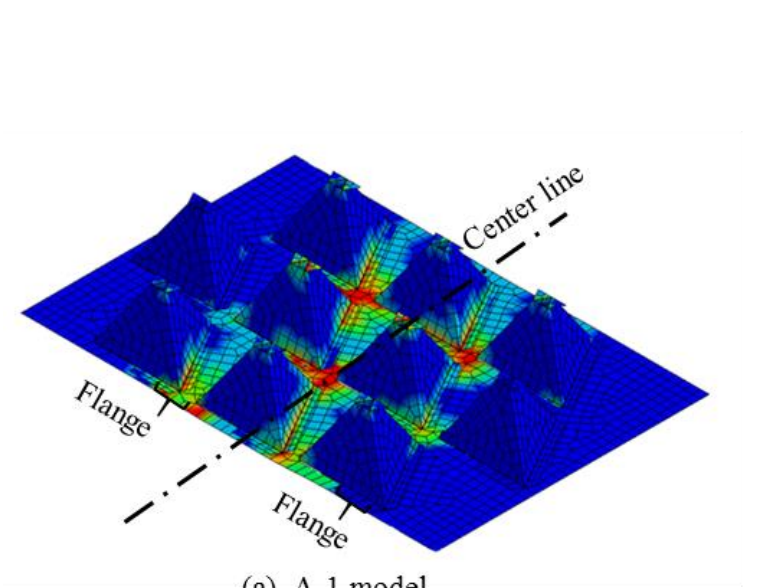

(a) A-1 model

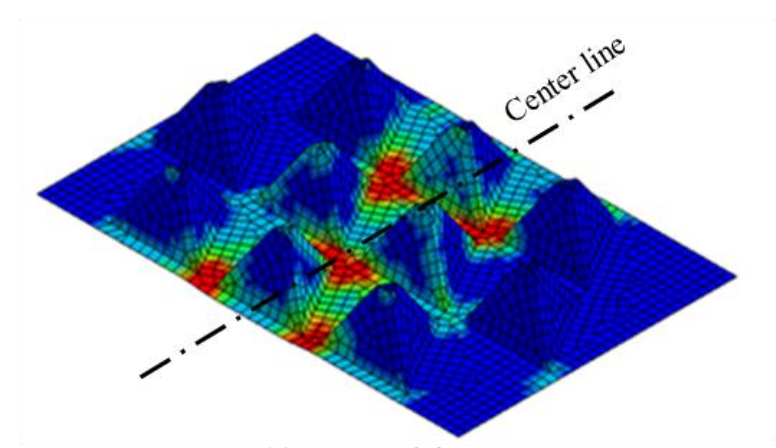

(c) B-1 model

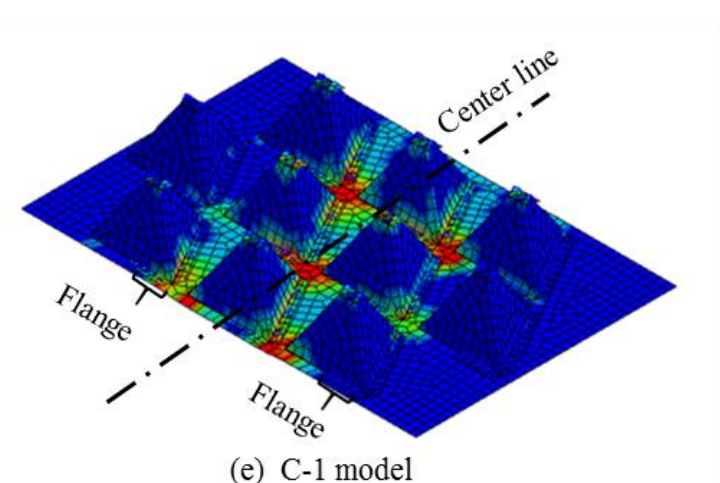

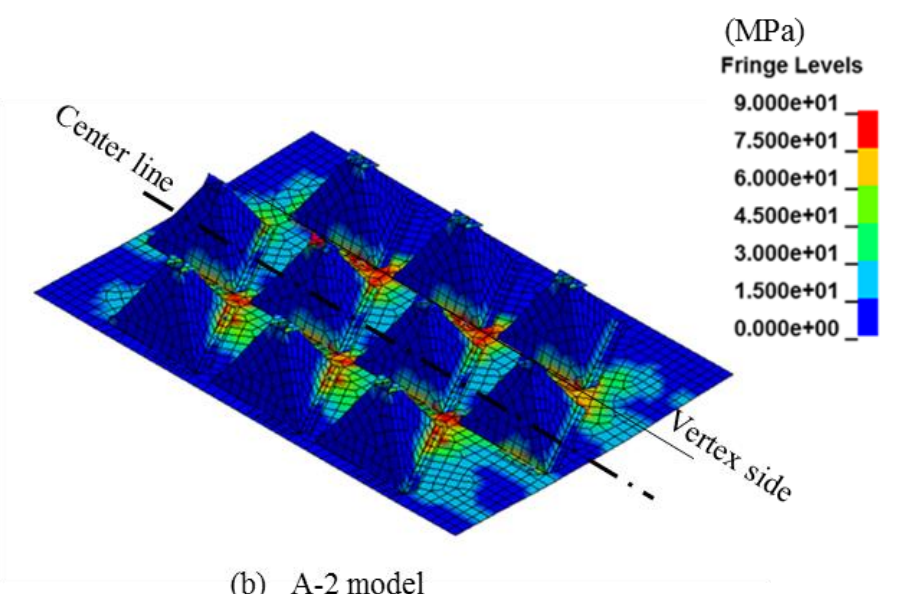

(b) A-2 model

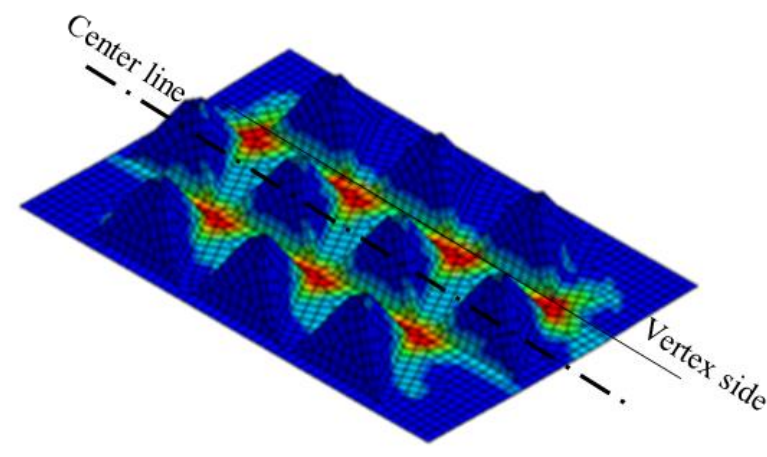

(d) B-2 model

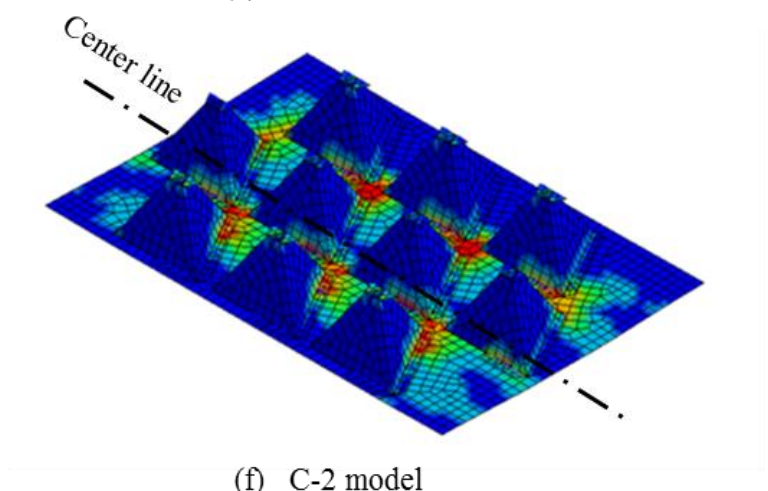

Fig.15 Mises stress distributions (MPa) at $\delta=5.0 \mathrm{~mm}$ by FEM results. The total number of red area that stress level in excess of $75 \mathrm{MPa}$ in B-1 model lower panel is 5 . The stress distribution of B-1 is symmetrical. But that of B-2 is not symmetrical.

The stress distributions of A\&C model show the stress concentrates at the contact area between lower panel and assembled cores.

b) 応力分布と変位量分布 : $\delta=5.0 \mathrm{~mm}$ における相当応力分布を図 15 , 変位量分布を図 16 に示す. 図では, 分布 の特徴をわかりやすく示すために upper Panel や治具類等を取り除いて lower panel の状況だけを表示している.

二本の support jig 間の中心線が幅方向にある B-1 モデル解析結果（図 15 (c)）では, Lower panel の中央に近い core と core の間に 75MPa を超す応力集中となっている赤色領域が, 中心線に対して対称的にはっきりと 5 箇所 あるのに対して，A-1 モデルではこのような応力集中の特徵がない. A-1 や C-1 モデルでは, core と core の間よ りも Lower panel と core の接合箇所近傍の接触面に応力集中領域がみられる.この試作品のフランジ位置（図 15 (a)，(e)）の非対称性の影響が表われている. 即ち，B-1 モデルの中心線の両側の応力分布は対称的であるが， A-1 モデルではフランジ位置が対称でない箇所があるため応力分布は対称性を欠いており，この特徵は接合点数 の多いC-1 モデルの方がより明確であり，Cモデルに異方性が強く表れる要因である。このように，AおよびC モデルでは，各 coreが Lower panel と連続体ではない組立構造として荷重を受けている状態を顕著に示している. 
次に, 二本の support jig 間の中心線が長さ方向にある B-2 モデル解析結果（図 15(d)）では, Lower panel の中 央に近い core と core $の$ 間に $75 \mathrm{MPa}$ を超す応力集中となっている赤色領域が 7 箇所ある. 中心線上にある core 列 の三角形底面の頂点側に 4 箇所, その反対側に 3 箇所あり, B-1 のように中心線に対して対称的な応力分布では ない．応力集中寸る core と core 間の領域が, B-2 の場合はB-1 と異なり, 中心線に対して対称になっていないから である.このような core 配置パターン特性があるため，二本の support jig 間の中心線の設定方向によって，曲げ 剛性に異方性が表れることになる.

また, $\delta=5.0 \mathrm{~mm}$ における変位量分布図（図 16）からも, 中心線が幅方向の場合は, 変位量最大域の青色領域 は中央部の 2 個の core で, 中心線に隣接する support jig ピッチ $476 \mathrm{~mm}$ 内にある左右 1 個ずつの core が変形抵抗 に大きく寄与寸る. 他方, 中心線が長さ方向の場合には中央部 4 個の core がそろって変位量最大域の青色領域と なり，その隣の core 列は support jig ピッチ $476 \mathrm{~mm}$ 内には core 底面の一部しか含まれない. その結果, 前者より

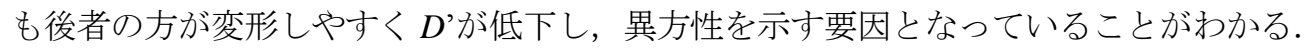

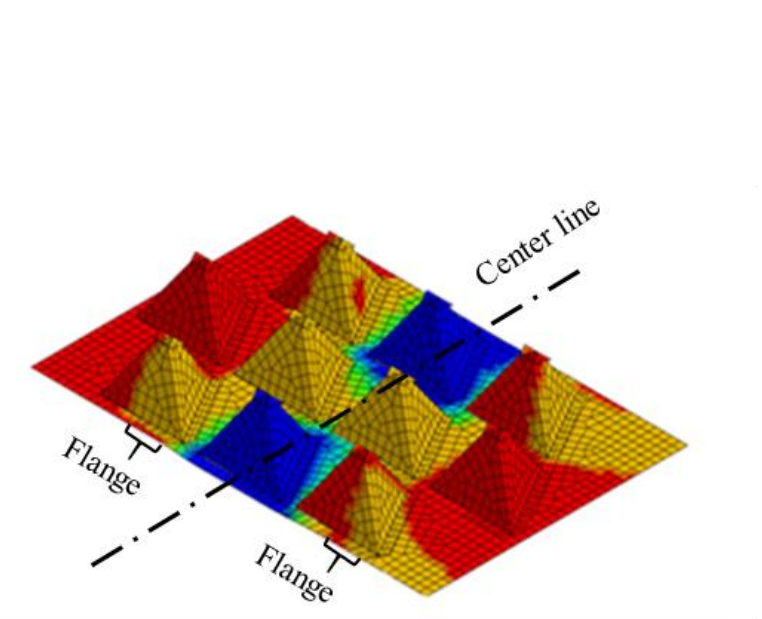

(a) A-I model

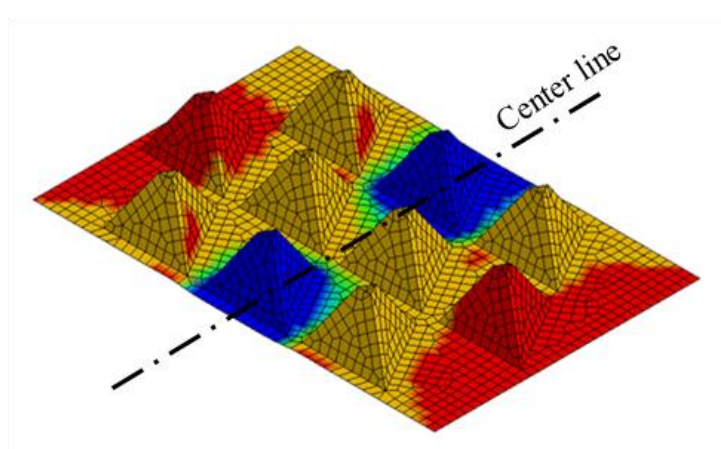

(c) B-1 model

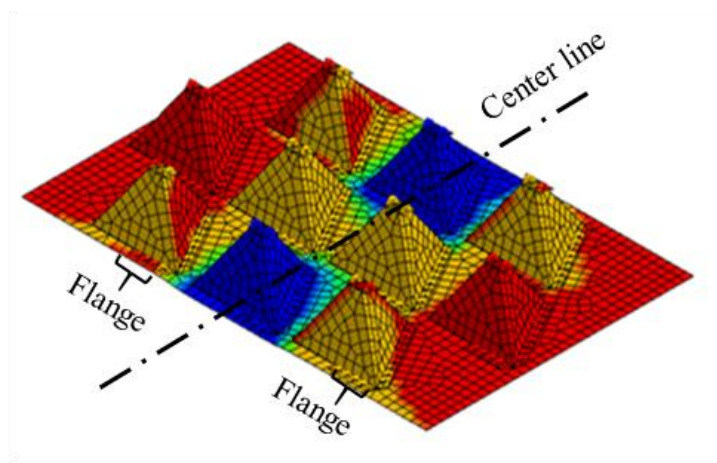

(e) C-1 model

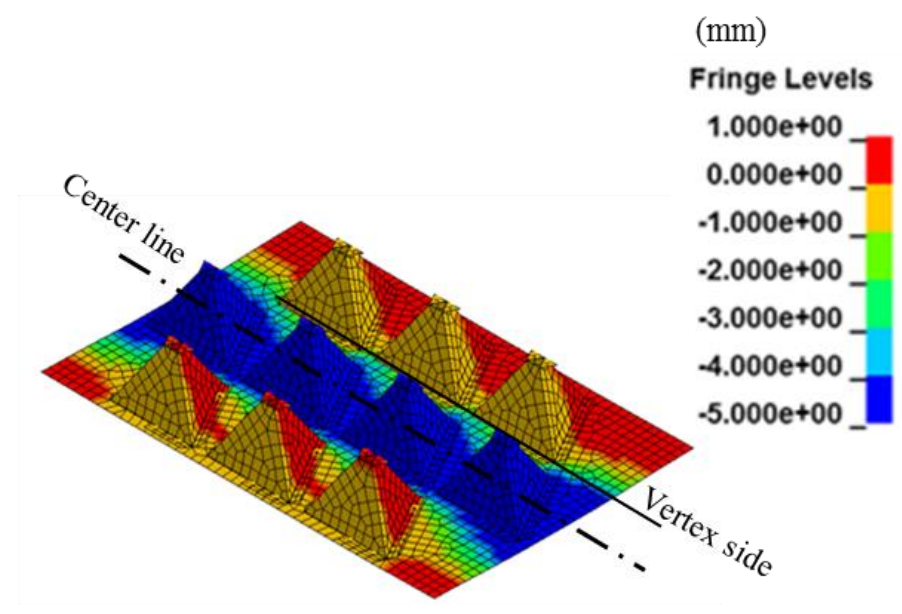

(b) A-2 model

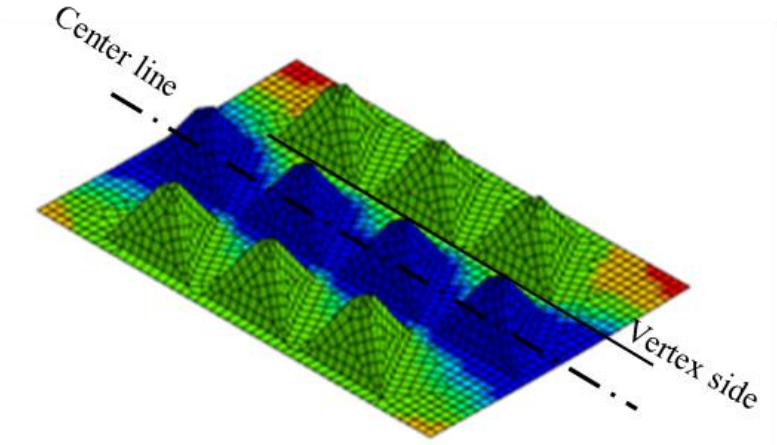

(d) B-2 model

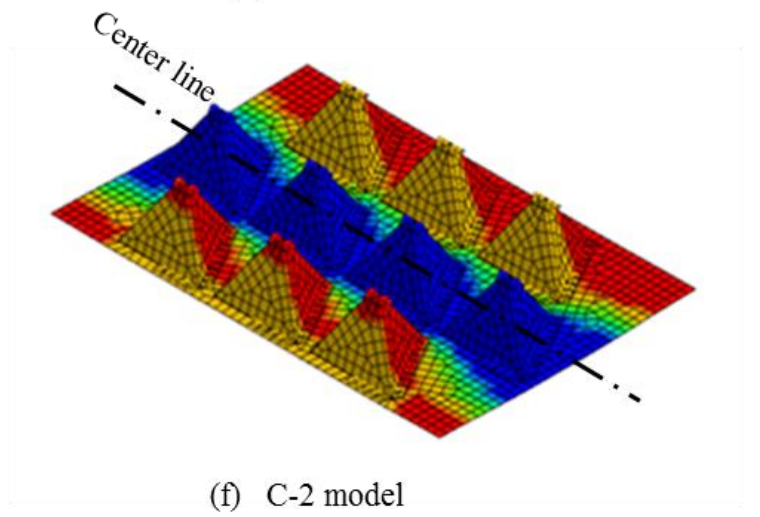

Fig.16 The displacement distributions $(\mathrm{mm})$ by FEM results. The 4 cores at the center line are blue area at the cases of jigs setting along the long direction. On the other hand, the 2 cores at the center line are blue area at the cases of jigs setting along the width direction. It shows that D' has anisotropy characteristic. 


\section{5. 結言}

本稿では, 新しい軽量高剛性構造パネルとして組立式トラスコアパネル(ATCP) 工法と構造を提案し, 試作品を 製作して曲げ剛性試験と FEM 解析を行う等の取組から，次のような知見が得られている.

（1）コアを曲げ加工し組立てることにより ATCP を試作して，3 点曲げ剛性試験による曲げ剛性評価を行った結 果, 従来の TCP よりも大幅にアスペクト比が向上した形状自由度の高いATCP工法と構造の可能性を示している.

(2) 組立式軽量高剛性構造パネルの主な仕様として, 素材機械的性質, 形状寸法, 板厚, 折線溝条件 (深さ, 幅), 組立条件（合わせ面の接触面積，接合点数など）等を考慮できる FEM 解析による ATCP 曲げ剛性評価手法につ いて報告し，実験による曲げ剛性試験測定結果と精度よく一致することを示して，その有効性を検証している.

(3) ATCP についての FEM 解析による変形解析結果では, 今回の試作品の組立条件での Lower panel 変形は, コ アとの接合箇所における接触面を介して荷重を受ける傾向が強いため, 応力集中箇所は少なく全体的に撓む組立 構造の特徴を明確に示している.

(4)従来の TCP のプレス加工金型, HCP の接着剤や複雑な組立工程等を必要とせず，早急に簡便な設備で製造で きるATCP は, ブラインドリベットの使用により外観はよくないが, 緊急の構造物構造補強材料あるいは多品種少 量生産の機械および建築構造物の内部構造補強材料として実用化が期待できる.

また，今後の大量生産品としての ATCP 実用化のために，次のような課題について研究開発を進めていく.

（1）品質管理的には，曲げ加工用折線上に設定する溝条件(深さ，幅)の加工性への影響を把握して, スプリング バックを抑制し形状寸法精度を確保できる適正な曲げ加工条件範囲を成形シミュレーション等から事前検討し, 各種金属材料に対応できる ATCP 製造条件範囲を明確化する.

（2）コスト的には，多種多様なコアを大量生産する必要があり，コア曲げ加工〜組立までの作業に適用できるロ ボット等を用いた自動化による生産性向上策を解決する.

\section{文献}

萩原一郎，八ニカムよりも安いパネル鋼板 2 枚を型押しして溶接，Automotive Technology(2011), pp.96-101. 萩原一郎, 計算力学と折紙工学融合による新しい軽量コア構造の機能創出と製造法に関する研究, 課題番号

20226006, 科研費研究成果報告書 (2013).

桑原俊彦, 梅村昌史, 吉田健吾, 黒田充紀, 平野清一, 菊田良成, $\mathrm{Mg}$ 量の異なる 5000 系アルミニウム合金板の成 形限界ひずみ, 軽金属, Vol. 56, No.6 (2006), pp. 323-328.

LS-DYNA Version 971 User's Manual (2012).

グエン・タイ・タット・ホアン, 寺田耕輔, 戸倉直, 萩原一郎, トラスコアの設計自由度を高めるための折紙工

法の開発，日本機械学会論文集 A 編，Vol. 80, No. 819 (2014), DOI: 10.1299/transjsme.2014smm0314.

小川秀夫, 牧野内昭武, くさび型工具の押し込みによる金属板材のシャープ曲げ加工, 塑性と加工(日本塑性加工 学会誌), Vol.40, No.459 (1999), pp.338-342.

小川 孝行, 吉田 総仁, 高張力鋼板のU 曲げスプリングバックの抑制に及ぼす決め押しの効果, 塑性と加工,

Vol. 53, No.612 (2012), pp.69-73.

斎藤一哉, 野島武敏, 平面/空間充填形に基づく新しい軽量高剛性コアパネルのモデル化, 日本機械学会論文集A

編, Vol. 73, No. 735 (2007), pp. 1302-1308.

斉藤一哉, 野島武敏, 新しく開発した軽量コアパネルの幾何学的パターンと機械的特性の関係, 日本機械学会論

文集A編，Vol. 74, No. 748 (2008)，pp. 1580-1586.

斉藤一哉, 野島武敏, 森村浩明, 萩原一郎, 新しく開発した軽量コアパネルの曲げ岡性の評価, 日本機械学会論

文集 A 編, Vol.75, No.750 (2009), pp.259-265.

斉藤一哉, 野島武敏, 任意断面を持つハニカムコアの展開図設計法，日本機械学会論文集A編，Vol. 78, No. 787 (2012), pp. 324-335.

田村 翔平, 澄川 智史, 上森 武, 濱崎 洋, 吉田 総仁, 5000 系および 6000 系アルミニウム合金板における弾塑 性挙動の実験観察，軽金属，Vol. 61, No. 6 (2011)，pp. 255-261. 
寺田耕輔, ロンドン Robofold 訪問記, 平成 25 年度文部科学省数学・数理科学と諸科学・産業との連携研究ワーク ショップ, 明治大学中野キャンパスにて招待講演(2014).

戸倉直, 萩原一郎, トラスコアパネルの製造シミュレーション, 日本機械学会論文集 A 編, Vol. 74, No. 746 (2008), pp. 1379-1385.

\section{References}

Hagiwara, I., Welding by pressing 2 sheets of cheaper steel panel than honey comb, Automotive Technology (2011), pp.96-101 (in Japanese) .

Hagiwara, I., KAKENHI No.20226006, Research on the manufacturing method and creating the function of new lightweight core structure by fusion of the origami engineering and the computational mechanics (2013), (in Japanese).

Kuwabara, T., Umemura, M., Yoshida, K., Kuroda, M., Hirano, S. and Kikuta, Y., Forming limit strains of 5000 series aluminum alloys with different magnesium contents, Journal of Japan Institute of Light Metals, Vol. 56, No.6 (2006), pp.323-328 (in Japanese).

LS-DYNA Version 971 User's Manual (2012).

Nguyen, T. T. H., Terada, K., Tokura, S. and Hagiwara, I., Development of origami forming to improve the flexibility of truss core panel design, Transactions of the JSME (in Japanese),

Vol.80,No.819 (2014) , DOI: 10.1299/transjsme.2014smm0314.

Ogawa, H. and Makinouchi, A., Sharp bending of sheet metal with indentation of V-shaped punch, Journal of the Japan society for technology of plasticity, Vol.40, No.459 (1999), pp.338-342 (in Japanese).

Ogawa, T. and Yoshida, F., Effect of bottoming on reduction of springback in U-bending of high-strength steel sheet, Journal of the Japan Society for Technology of Plasticity, Vol. 53, No. 612 (2012), pp. 69-73 (in Japanese).

Saito, K. and Nojima, T., Modeling of new light-weight, rigid core panels based on geometric plane tilings and space filings, Transactions of the Japan Society of Mechanical Engineers, Series A, Vol. 73, No.735 (2007) , pp. 1302-1308 (in Japanese).

Saito, K., Nojima, T. and Hagiwara, I., Relation between geometrical patterns and mechanical properties in newly developed light-weight core panels, Transactions of the Japan Society of Mechanical Engineers, Series A, Vol.74, No.748 (2008), pp.1580-1586 (in Japanese).

Saito, K., Nojima, T., Morimura, H. and Hagiwara, I., Evaluation of bending rigidity in newly developed light-weight core panels, Transaction of the Japan Society of Mechanical Engineers, Series A, Vol. 75, No.750 (2009), pp. $259-265$ (in Japanese).

Saito, K. and Nojima, T., Designing method for a folding line diagrams of arbitrary cross-section honeycomb cores, Transactions of the Japan Society of Mechanical Engineers, Series A, Vol.78, No.787 (2012), pp. 324-335 (in Japanese) .

Tamura, S., Sumikawa, S., Uemori, T., Hamasaki, H. and Yoshida, F., Experimental observation of elasto-plasticity behavior of type 5000 and 6000 aluminum alloy sheets, Journal of Japan Institute of Light Metals, Vol. 61, No.6 (2011), pp.255-261 (in Japanese).

Terada, K., Collaboration with Robofold in London, 2013 fiscal year the Ministry of Education, Collaborative research work shop with mathematics, mathematical sciences, sciences and industry, Invited lecture at Meiji University (2014) (in Japanese).

Tokura, S. and Hagiwara, I., Forming process simulation of truss core panel, Transactions of the Japan Society of Mechanical Engineers, Series A, Vol.74, No.746 (2008), pp. 1379-1385 (in Japanese) . 